\title{
Implementasi Sistem Informasi Berbasis QR Code Guna Mencegah Kerumunan dalam Antrian Wisuda
}

\author{
${\text { Dani Anggoro*1, Dolly Virgian Shaka Yudha Sakti }{ }^{2} \text {, Sejati Waluyo }}^{3}$ \\ ${ }^{1}$ Program Studi Ilmu Komputer, Universitas Muhammadiyah Metro* \\ ${ }^{2,3}$ Program Studi Teknik Informatika, Universitas Budi Luhur \\ email: anggoro.dani1@gmail.com*1, dolly.virgianshaka@budiluhur.ac.id ${ }^{2}$, \\ sejati.waluyo@budiluhur.ac.id ${ }^{3}$
}

(Received: 29 April 2021/ Accepted: 28 Mei 2021 / Published Online: 20 Juni 2021)

\begin{abstract}
Abstrak
Wisuda adalah acara pengukuhan untuk mahasiswa yang telah menyelsaikan studi di perguruan tinggi. Acara ini dihadiri oleh banyak orang di dalam ruangan. Pandemi Covid-19 mengharuskan kita untuk beradaptasi dengan kebiasaan baru, begitu juga dengan acara wisuda. Acara tidak dapat diselenggarakan seperti biasa karena setiap orang harus menjalankan protokol kesehatan, seperti menjaga jarak antar orang dan tidak berkumpul di dalam ruangan. Wisuda secara online dapat menjadi solusi, tetapi wisuda langsung lebih diharapkan oleh mahasiswa dan orang tua. Tujuan penelitian ini adalah mengimplemntasikan sistem informasi berbasis $Q R$ Code untuk mencegah kerumunan dalam ruangan dan mengatur antrian wisuda. Metode yang digunakan dalam membangun sistem menggunakan Prototype Model dengan tahapan, yakni menganalisa data, merancang sistem menggunakan diagaram $U M L$, pengkodean menggunakan bahasa pemograman PHP Native dan pengujian menggunakan Black Box Testing. Hasil dari penelitian ini adalah aplikasi berbasis web yang mampu membaca $Q R$ Code dari mahasiswa. Hasil pengujian menunjukan bahwa aplikasi yang di buat dapat menjadi solusi dalam menyelengarakan wisuda langsung pada masa adaptasi kebiasaan baru pada saat pandemi Covid-19.
\end{abstract}

Kata kunci: Adaptasi Kebiasaan Baru, QR Code, Sistem Informasi, Wisuda

\begin{abstract}
Graduation is an inauguration event for students who have completed their studies at university. This event was attended by many people in the room. The Covid-19 pandemic requires us to adapt to being new normal, as well as graduation events. Events cannot be held as usual because everyone must follow health protocols, such as maintaining distance between people and not gathering indoors. Online graduation can be a solution, but in-person graduation is more expected by students and parents. The purpose of this study is to implement a QR Code-based information system to prevent indoor crowds and manage graduation queues. The method used in building the system is a prototype model with stages, namely analyzing data, designing the system using UML diagrams, coding using the PHP Native programming language and testing using Black Box Testing. The result of this research is a web-based application that can read QR Code from students. The test results show that the application created can be a solution in holding graduation directly during the adaptation period of new habits during the Covid-19 pandemic.
\end{abstract}

Keywords: New Normal, QR Code, Information Systems, Graduation

\section{PENDAHULUAN}

Semakin majunya perkembangan teknologi akan memberikan pengaruh dalam berbagai aspek kehidupan baik di bidang pemerintah, perusahaan dan pendidikan (Muharom, 2016). Salah satu teknologi yang yang saat ini sering digunakan dalam mengakses informasi atau data adalah teknologi QR Code atau Quick Response Code. Teknologi ini adalah semacam 
simbol dua dimensi yang dikembangkan oleh Denso Wave pada tahun 1994. Tujuan dari teknologi ini adalah menyampaikan informasi secara cepat serta respon yang juga cepat (Azizah, Soleh, \& Astuti, 2019) Dengan kecepatan dan keakuratan yang baik, teknologi ini tentunya dapat diimplementasikan kedalam sebuah sistem informasi. Sistem yang baik akan berpengaruh terhadap segala informasi yang akan dihasilkan sedangkan informasi merupakan data-data yang masih mentah kemudian diolah agar menjadi bentuk yang berguna untuk memperoleh suatu keputusan (Muntohar, 2020)). Menurut (Krismiaji, 2015) sistem informasi merupakan cara yang terorganisir dalam mengumpulkan, memasukan, mengelola dan melaporkan informasi sehingga mencapai tujuan yang diinginkan.

Pada awal tahun 2020 dunia dikejutkan oleh adanya penyakit Coronavirus Disease 2019 (Covid-19). Pada bulan Maret 2020 ditemukan kasus positif Covid-19 di Indonesia. Pada awalnya ada yang menyebut virus ini dengan nama pneumonia Wuhan dan novel coronavirus pneumonia. WHO sebagai organisasi kesehatan dunia akhirnya memberi nama virus ini dengan nama Coronavirus Disease 2019(Gorbalenya et al., 2020). Penyakit ini dapat menyebar dari satu orang atau benda ke orang atau benda yang lain. Atas dasar ini yang akhirnya membuat kita harus melakukan protokol pencegahan dan pengendalian Covid-19 di dalam kegiatan kita sehari-hari (Jin et al., 2020).

Proses wisuda adalah kegiatan yang melibatkan banyak orang dalam satu ruangan. Proses ini biasanya diawali dengan masuknya rektor beserta pembantu rektor dan dekan yang akan mewisuda para calon wisudawan dan wisudawati (Rifai, Retnoningsih, Hari, \& Al, 2017). Proses tersebut dapat menyebabkan kerumuan dalam ruangan, sebagai solusi dari masalah tersebut maka perlu diabuatkan sistem informasi berbasisi $Q R$ Code yang mengatur antrian sekaligus dapat menghindari kontak langsung dengan orang lain.

Penelitian sebelumnya terkait sistem informasi berbasis $Q R$ Code diantaranya adalah penelitian yang dilakukan oleh Azizah dengan judul Perancangan Sistem Koperasi Karyawan Menggunakan QR Code Untuk Meningkatkan Pelayanan Pada Koperasi PT. Intikemas Putra Makmur (Azizah et al., 2019) hasil dari penelitian mereka adalah berupa sistem informasi koperasi menggunakan $Q R$ Code. Hasil temuan mereka menyimpulkan bahwa menerapkan $Q R$ Code pada sistem informasi koperasi dapat mempermudah anggota dalam bertransaksi dan mendapatkan laporan. Penalitain yang dilakukan oleh Agus, dengan judul Sistem Peminjaman Barang Inventaris Media Perkuliahan Berbasis $Q R$ Code Sebagai Pendamping Sistem Konvensional Untuk Pengelolaan Barang (Setiawan, 2019) hasil dari penelitian tersebut berupa sistem untuk mendata barang menggunakan $Q R$ Code, dengan kesimpulan bahwa dengan mengimplementasikan $Q R$ Code dapat mempermudah pendataan barang di sistem peminjaman barang, Penelitian selanjutnya dilakukan oleh Aini dengan judul Penerapan QRCode Sebagai Media Pelayanan Untuk Absensi Pada Website Berbasis PHP Native (Aini, Rahardja, \& Fatillah, 2018) serta labolo dengan judul Implementasi QRCode Untuk Absensi Perkuliahan Mahasiswa Berbasis Paperless Office (Labolo, 2019). Hasil dari penelitian mereka berupa sistem informasi untuk presensi menggunakan $Q R$ Code, kesimpulan dari penelitian ini yaitu penggunaan $Q R$ Code lebih ramah lingkungan dan efisien karena tidak memerlukan kertas. Perbedaan penelitian ini dengan penelitian yang sebelumnya adalah pada penelitian yang dibuat sebelumnya lebih fokus ke efektifitas dan efisiensi sistem informasi yang mengimplementasikan $Q R$ Code, sementara penelitian ini lebih fokus kepada penggunaan sistem informasi berbasis $Q R$ Code untuk membantu penerapan protokol kesehatan saat memasuki masa kebiasaan baru pandemi covid19.

\section{METODE}

Prototype model adalah salah satu paradigma dalam mengembangkan perangkat lunak. Dengan menggunakan model ini pengembang dan pengguna sistem akan saling berinteraksi selama pembuatan aplikasi (Hidayat, Irmayanti, \& Tommy, 2020; Khoiriyah \& Manikam, 
2019). Prototype model merupakan suatu teknik dalam mengumpulkan informasi tentang kebutuhan informasi pengguna secara cepat (Akbar \& Gunawan, 2020; Ramadhan \& Santika, 2020). Prototipe akan dievaluasi oleh pengguna dan dapat digunakan untuk menyaring kebutuhan dalam membangun sistem informasi (Susanto \& Andiana, 2016). Model ini (lihat gambar 1) dipilih dalam penelitian ini karena lebih cocok untuk sistem yang bersifat customize (sesuai permintaan pengguna berdasarkan situasi dan kondisi). Sistem dibangun dengan mengumpulkan data, menganalisa data, merancang sistem dan mengevaluasi sistem.

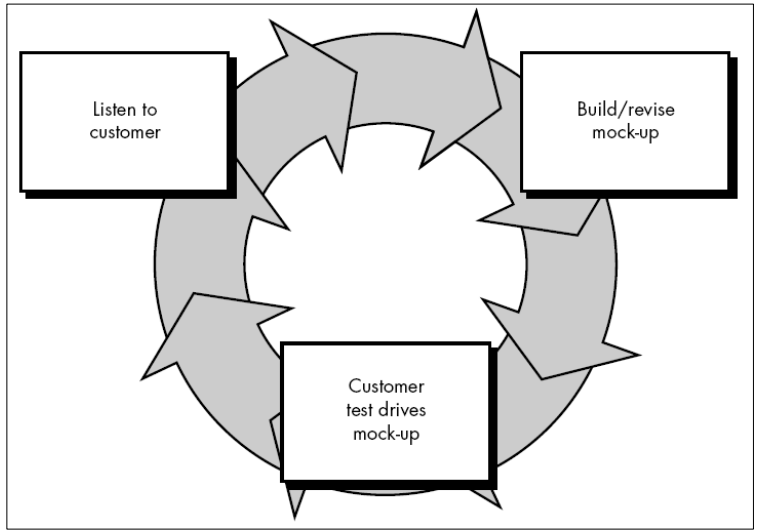

Gambar 1. Prototype Model

Pengumpulan data dilakukan dengan cara mengumpulkan data calon wisudawan, setelah data diperoleh dibuat perancangan sistem menggunakan diagram-diagram $U M L$ untuk menggambarkan proses usulan, interaksi antara pengguna dan sistem dan perancangan basis data yang akan digunakan. UML merupakan salah satu metode pemodelan visual yang digunakan dalam perancangan dan pembuatan software dengan berorientasikan objek (Prihandoyo, 2018). Sistem yang dibangun berbasis website dengan menggunakan bahasa pemrograman PHP Native. PHP Native dipilih karena kode ini lebih ringkas dan ringan untuk membangun aplikasi web sederhana dibanding menggunakan framework (Padmanaba, Kumalasari, \& Andayati, 2020). Sedangkan untuk penyimpanan data menggunakan database MySQL (Lase \& Wijaya, 2018). Setelah perancangan dan pembuatan sistem informasi selesai selanjutnya akan dilakukan evaluasi. Metode yang akan digunakan dalam mengevaluasi sistem yaitu metode Black Box Testing. Black box Testing adalah suatu metode untuk menguji aplikasi yang telah dibuat dari aspek fungsional tanpa menguji desain dan kode program (Sukamto \& Shalahuddin, 2015).

\section{HASIL DAN PEMBAHASAN}

Hasil

\section{Pengumpulan Data}

Hasil pengumpulan data diperoleh data informasi mengenai daftar peserta wisuda dan kapasitas ruangan yang digunakan untuk prosesi wisuda. Berdasarkan data tersebut akan di bagi jadual atau sesi wisuda. Data tersebut juga akan digunakan sebagai acuan dalam merancang basis data yang akan digunakan sebagai database dalam sistem informasi. Tabel peserta wisuda dapat dilihat pada Tabel 1. Berdasarkan data yang terdapat pada tabel 1 diperoleh jumlah peserta wisuda pada periode tersebut adalah 1.218 mahasiswa. Supaya tidak terjadi kerumunan saat prosesi wisuda jumlah peserta yang hadir dibatasi dengan hari dan sesi wisuda. Data hari dan sesi wisuda untuk fakultas teknologi informasi dapat dilihat pada tabel 2. 
Tabel 1. Daftar Peserta Wisuda

\begin{tabular}{cc}
\hline Fakultas & Jumlah Peserta Wisuda \\
\hline Teknologi Informasi & 384 \\
Ilmu Komunikasi & 306 \\
Ekonomi dan Bisnis & 396 \\
Sosial danPolitik & 87 \\
Teknik & 45 \\
\hline
\end{tabular}

Tabel 1. Daftar Peserta Wisuda Fakultas Teknologi Informasi

\begin{tabular}{cccc}
\hline Tanggal Wisuda & Sesi Wisuda & Jam & Jumlah Peserta \\
\hline 23-02-2021 & 1 & $08: 00-09: 00$ & 50 \\
23-02-2021 & 2 & $09: 00-10: 00$ & 50 \\
$\mathbf{2 3 - 0 2 - 2 0 2 1}$ & 3 & $10: 00-11: 00$ & 50 \\
$\mathbf{2 3 - 0 2 - 2 0 2 1}$ & 4 & $11: 00-12: 00$ & 50 \\
$\mathbf{2 3 - 0 2 - 2 0 2 1}$ & 5 & $13: 00-14: 00$ & 50 \\
$\mathbf{2 4 - 0 2 - 2 0 2 1}$ & 1 & $08: 00-09: 00$ & 50 \\
$\mathbf{2 4 - 0 2 - 2 0 2 1}$ & 2 & $09: 00-10: 00$ & 50 \\
$\mathbf{2 4 - 0 2 - 2 0 2 1}$ & 3 & $10: 00-11: 00$ & 34 \\
\hline
\end{tabular}

\section{Perancangan Sistem}

Setelah diperoleh data peserta wisuda selanjutnya data dianalisis kemudian dibuat rancangan sistem informasi yang dibuat. Bentuk rancangan ditampilkan dalam bentuk diagram $U M L$ yang terdiri dari activity diagram untuk menggambarkan proses bisnis usulan, Gambar activity diagram dapat dilihat pada gambar 2.

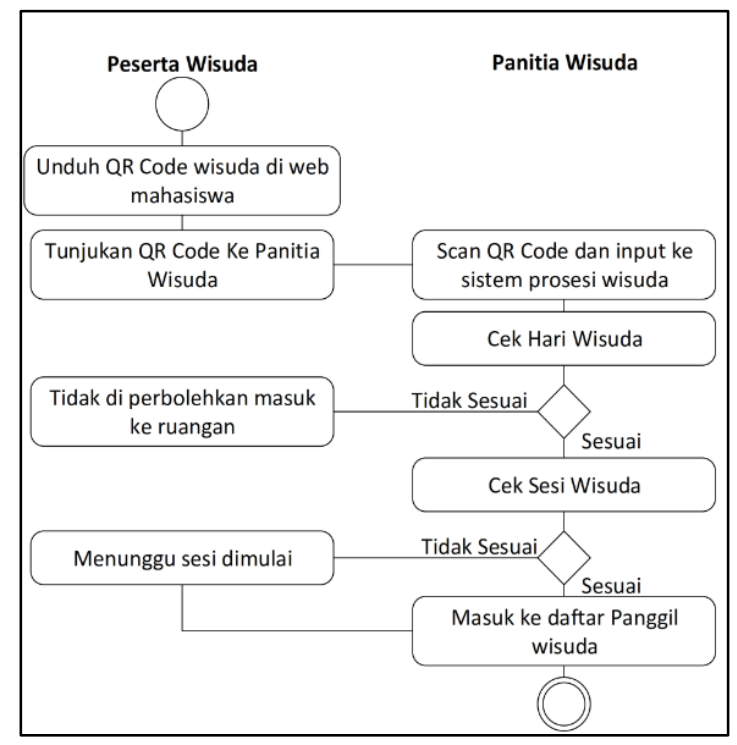

Gambar 2. Activity Diagram Proses Prosesi Wisuda

Use case diagram untuk menampilkan interksi antara pengguna dan sistem, use case diagram pada sistem yang dibuat dapat dilihat pada gambar 3. Class diagram untuk memperoleh gambaran rancangan basis data yang digunakan pada sistem yang dibuat dapat dilihat pada gambar 4 . 


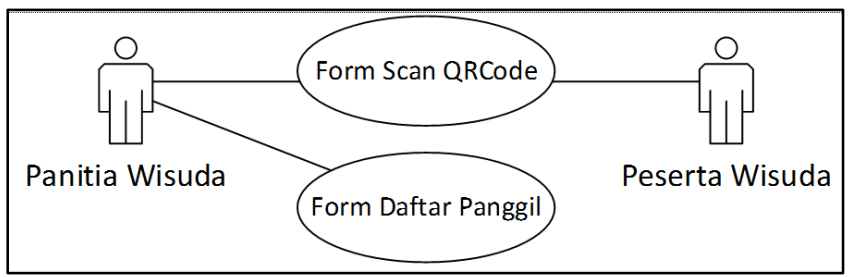

Gambar 3.Use Case Diagram

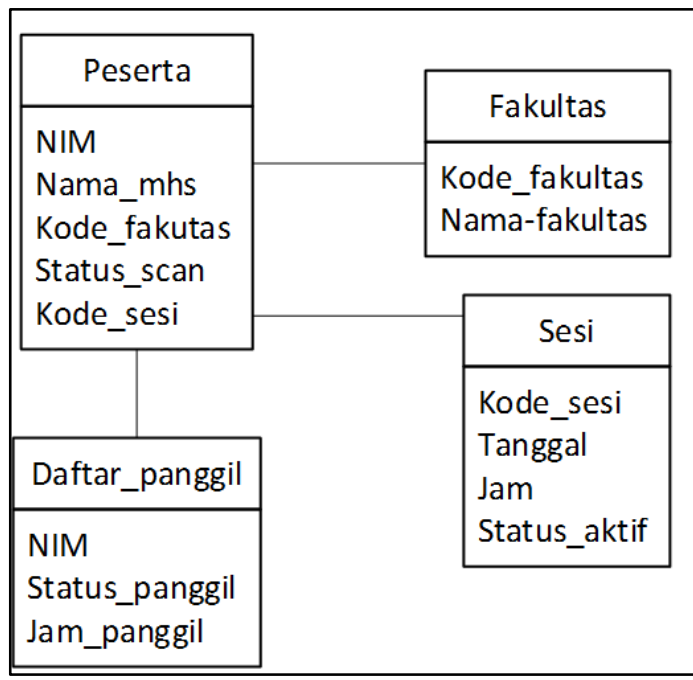

Gambar 4. Class Diagram

\section{Implementasi Sistem}

Implementasi sistem digambarkan dalam tampilan layar. Sistem yang dibangunmenggunakan bahasa pemograman PHP Native dengan desain tampilan menggunakan HTML dan CSS. Tampilan halaman depan dapat dilihat pada gambar 5. Selanjutnya, Pada halaman ini ditampilkan halaman utama untuk scan QR Code peserta wisuda. Pada tabel Peserta wisudawan akan di tampilkan data mahasiswa yang telah melakukan Scan QR Code. Jika peserta hadir sesuai sesi wisuda, peserta akan dipersilahkan memasuki ruangan wisuda kemudian langsung dipanggil oleh pembawa acara untuk di wisuda. Tampilan gambar untuk hari dan sesi yang sesuai dapat dilihat pada gambar 6.

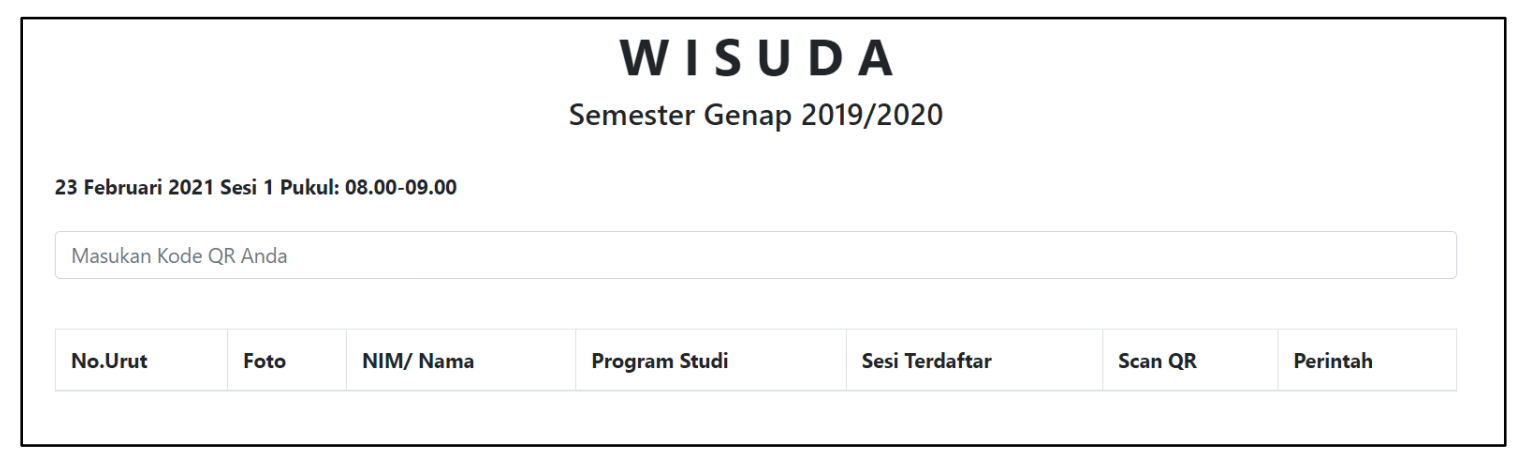

Gambar 5. Halaman Utama Scan QR Code 


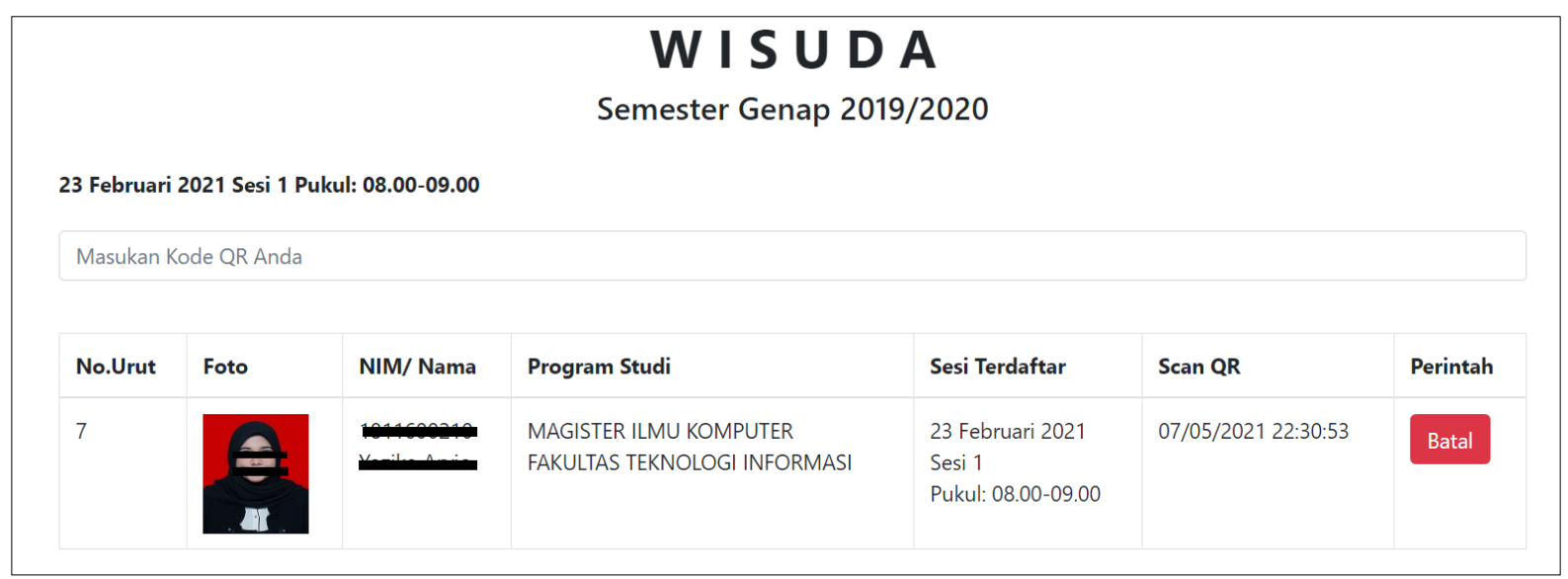

\section{Gambar 6. Tampilan Sesuai Hari dan Sesi}

Jika peserta hadir tidak sesuai sesi wisuda tetapi masih sesuai dengan hari wisuda, baris pada tabel peserta wisuda akan berwarna kuning, peserta akan diarahkan untuk menunggu di ruang tunggu. Tampilan untuk sesi yang tidak sesuai dapat lihat pada gambar 7. Sementara itu, jika peserta hadir tidak sesuai sesi dan tidak sesuai hari maka baris pada tabel peserta wisuda akan berwarna merah dan peserta tidak diminta untuk hadir sesuai sesi dan harinya. Tampilan dapat dilihat pada gambar 8 .

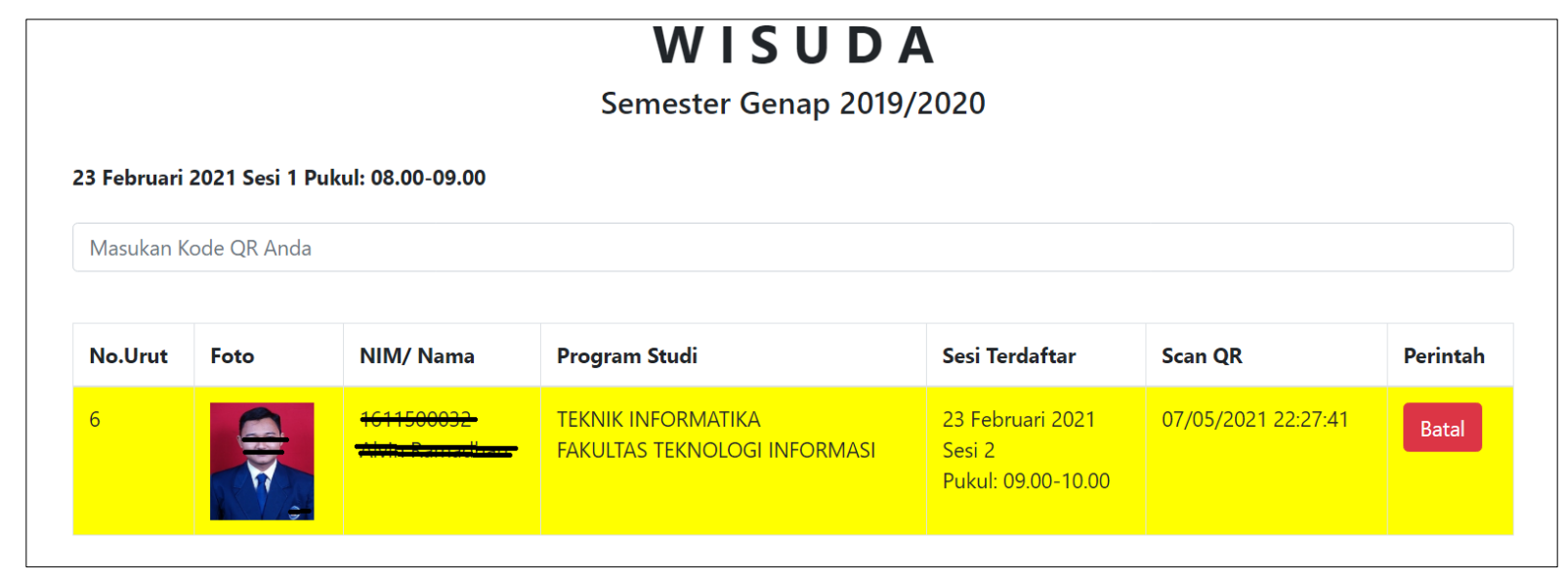

Gambar 7. Tampilan Sesuai Hari Tetapi Beda Sesi

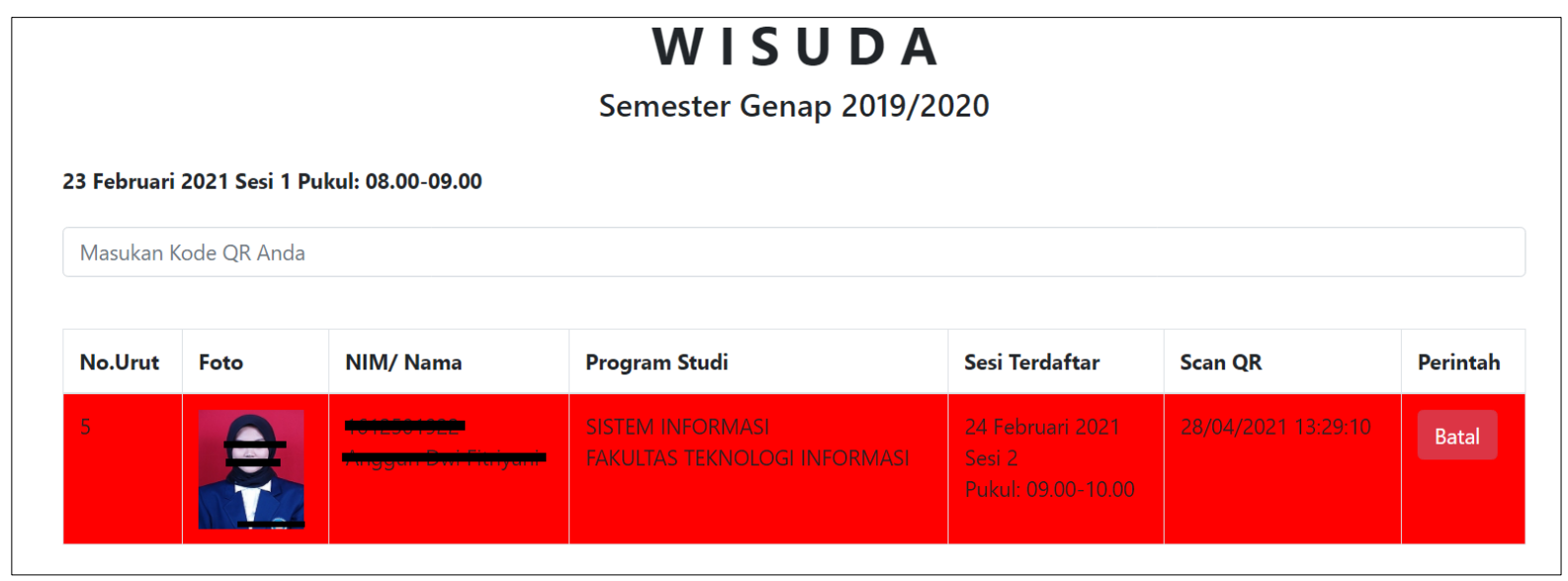

Gambar 8. Tampilan Hari dan Sesi Tidak Sesuai 
$Q R$ Code yang discan dapat diunduh di website mahasiswa, contoh $Q R$ Code dapat dilihat pada gambar 9 .

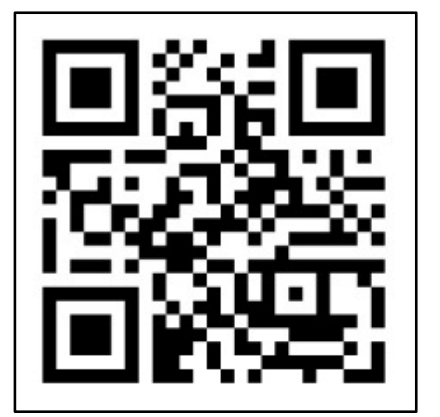

Gambar 9. QR Code Wisuda

\section{Evaluasi}

Pengujian dilakukan untuk mengetahui apakah sistem yang dibangun secara fungsional sudah sesuai dengan kebutuhan pengguna atau belum. Pada penelitian ini pengujian dilakukan menggunakan black box testing. Pengujian melibatkan pengguna sistem. Form yang diuji adalah form utama untuk scan $Q R$ Code.

Tabel 1. Hasil Pengujian Menggunakan Black Box Testing

\begin{tabular}{|c|c|c|c|}
\hline Pengujian & Harapan & Hasil & Kesimpulan \\
\hline $\begin{array}{l}\text { Scan } Q R \text { Code hari } \\
\text { sesuai, sesi sesuai }\end{array}$ & $\begin{array}{c}\text { Sistem menampilkan } \\
\text { data ke tabel peserta } \\
\text { wisuda }\end{array}$ & $\begin{array}{l}\text { Data berhasil } \\
\text { ditampilkan }\end{array}$ & Berhasil \\
\hline $\begin{array}{c}\text { Scan } Q R \text { Code hari } \\
\text { sesuai, sesi tidak sesuai }\end{array}$ & $\begin{array}{c}\text { Sistem menampilkan } \\
\text { data ke tabel peserta } \\
\text { dengan peringatan }\end{array}$ & $\begin{array}{l}\text { Data ditampilkan } \\
\text { dengan warna latar } \\
\text { belakang kuning }\end{array}$ & Berhasil \\
\hline $\begin{array}{l}\text { Scan } Q R \text { Code hari dan } \\
\text { sesi tidak sesuai }\end{array}$ & $\begin{array}{c}\text { Sistem menampilkan } \\
\text { data ke tabel peserta } \\
\text { dengan peringatan }\end{array}$ & $\begin{array}{c}\text { Data ditampilakan } \\
\text { dengan warna latar } \\
\text { belakang merah }\end{array}$ & Berhasil \\
\hline $\begin{array}{c}\text { Scan } Q R \text { Code } \\
\text { menggunakan data yang } \\
\text { sudah di scan }\end{array}$ & $\begin{array}{c}\text { Sistem menampilkan } \\
\text { peringatan }\end{array}$ & $\begin{array}{l}\text { Data gagal masuk } \\
\text { ke tabel dan } \\
\text { menampilkan } \\
\text { peringatan }\end{array}$ & Berhasil \\
\hline $\begin{array}{l}\text { Tombol batal untuk } \\
\text { membatalkan antrian }\end{array}$ & $\begin{array}{c}\text { Sistem akan } \\
\text { menghapus data dari } \\
\text { tabel peserta }\end{array}$ & $\begin{array}{c}\text { Data berhasil } \\
\text { dihapus dari tabel }\end{array}$ & Berhasil \\
\hline
\end{tabular}

\section{Pembahasan}

\section{Proses Bisnis Usulan}

Peserta wisuda menyiapkan $Q R$ Code yang sudah tersedia di web mahasiswa sebelum masuk ke ruang wisuda, panitia membuka aplikasi sistem informasi prosesi wisuda kemudian menscan $Q R$ Code tersebut dengan alat pemindai $Q R$ Code. Jika hari dan sesi wisuda sesuai dengan ada yang ada di sistem, peserta wisuda diperbolehkan masuk keruangan kemudian dipanggil oleh pembawa acara untuk di wisuda. Jika hari sesuai tetapi sesi tidak sesuai peserta wisuda dipersilakan menunggu di ruangan yang sudah disiapkan. Jika hari dan sesi tidak sesuai dengan sistem peserta tidak diijinkan masuk dan diminta untuk datang sesuai jadwal. 


\section{Interaksi Pengguna dengan Sistem}

Interaksi antar pengguna dan sistem di gambarkan pada gambar 2. Terdapat dua form yang ada pada sistem ini, form pertama adalah form scan $Q R$ Code untuk melakukan scan dan form kedua adalah form daftar panggil yang di gunakan untuk memangil peserta yang memenuhi syarat.

\section{Rancangan Basis Data}

Gambaran basis data dapat dilihat pada gambar 3 yang terdapat empat tabel, yakni tabel peserta di gunakan sebagai master data peserta wisuda, tabel sesi di gunakan untuk master data sesi wisuda. Tabel peserta dan tabel sesi berelasi. Tabel fakultas digunakan untuk menyimpan data fakultas, sedangkan tabel daftar panggil digunakan untuk menyimpan data peserta yang memenuhi syarat untuk dipanggil mengikuti prosesi wisuda.

\section{Hasil Evaluasi}

Hasil dari evaluasi menunjukan bahwa sistem yang dibangun dapat menjadi solusi untuk menghindari kerumunan dalam ruangan. Hasil Scan $Q r$ Code akan memeriksa hari dan sesi wisuda. Jika jadwal tidak sesuai sistem akan menampilkan peringatan. Berdasarkan pengujian yang dilakukan, sistem berhasil menampilkan peringatan jika terdapat perbedaan jadwal. Dengan adanya sistem ini peserta yang datang tidak sesuai jadwal dan sesi tidak dapat masuk ke ruangan prosesi wisuda. Selain itu penggunaan $Q R$ Code dapat menghindari kontak langsung dengan pantia wisuda.

\section{SIMPULAN}

Sistem informasi prosesi wisuda berbasis QR Code dibangun menggunakan prototype model. menggunakan $P H P$ sebagai bahasa pemrograman dan desain tampilan menggunakan $H T M L$ dan CSS. Hasil dari penelitian ini sebuah sistem informasi berbasis $Q R$ Code yang dapat mengatur antrian masuk wisuda. Sistem ini dapat digunakan dalam prosesi wisuda di masa kebiasaan baru pandemi covid-19.

\section{REFERENSI}

Aini, Q., Rahardja, U., \& Fatillah, A. (2018). Penerapan QR Code Sebagai Media Pelayanan Untuk Absensi Pada Website Berbasis PHP Native. Sisfotenika, 8(1), 47.

Akbar, T., \& Gunawan, I. (2020). Prototype Sistem Monitoring Infus Berbasis IoT (Internet Of Things). Edumatic: Jurnal Pendidikan Informatika, 4(2), 155-163.

Azizah, N., Soleh, O., \& Astuti, N. Y. (2019). Perancangan Sistem Koperasi Karyawan Menggunakan QR Code Untuk Meningkatkan Pelayanan Pada Koperasi PT. Intikemas Putra Makmur. Jurnal SENSI, 5(2), 175-189.

Gorbalenya, A. E., Baker, S. C., Baric, R. S., de Groot, R. J., Drosten, C., Gulyaeva, A. A., Ziebuhr, J. (2020). The species Severe acute respiratory syndrome-related coronavirus: classifying 2019-nCoV and naming it SARS-CoV-2. Nature Microbiology, 5(4), 536544.

Hidayat, R., Irmayanti, A., \& Tommy, M. (2020). Implementasi Multi Factor Evaluation Process untuk Penentuan Tempat Pembuangan Akhir Berbasis Web Aplication. Edumatic: Jurnal Pendidikan Informatika, 4(2), 103-111.

Jin, Y., Yang, H., Ji, W., Wu, W., Chen, S., Zhang, W., \& Duan, G. (2020). Virology, epidemiology, pathogenesis, and control of covid-19. Viruses, 12(4), 1-17.

Khoiriyah, S., \& Manikam, R. M. (2019). Analisa dan Perancangan Sistem Perhitungan Insentif Marketing Trade Menggunakan Sistem Remunerasi. EDUMATIC: Jurnal Pendidikan Informatika, 3(2), 99-108. https://doi.org/10.29408/edumatic.v3i2.1691

Krismiaji. (2015). Sistem Informasi Akuntansi (4th ed.). Yogyakarta: YKPN Yogyakarta.

Labolo, I. (2019). Implementasi QRCode Untuk Absensi Perkuliahan Mahasiswa Berbasis Paperless Office. Jurnal Informatika Upgris, 5(1), 1-4. 
Lase, D., \& Wijaya, V. (2018). Sistem Informasi Perpustakaan Pada Sekolah Menegah Atas Negeri 1 Tuhemberua Berbasis Web. Jurnal Armada Informatika, 2(2), 11-22. https://doi.org/10.36520/jai.v2i2.24

Muharom, L. A. (2016). Penerapan Model Presensi Ujian Semester Berbasis Quick Response Code (QR Code) di Universitas Muhammadiyah Jember. Jurnal Sitem \& Teknologi Informasi Indonesia, 1(2), 113-122.

Muntohar, A. (2020). Sistem Informasi Data Klien Berbasis Java Pada Kantor Notaris dan PPAT Arif. Edumatic: Jurnal Pendidikan Informatika, 4(2), 58-67. https://doi.org/10.29408/edumatic.v4i2.2515

Padmanaba, A., Kumalasari, E., \& Andayati, D. (2020). Komparasi Penggunaan Framework Codeigniter Vs Php Native Pada Sistem Informasi Manajemen Surat Sekretariat Dprd Pemalang. Jurnal SCRIPT, 8(1), 1-6.

Prihandoyo, M. T. (2018). Unified Modeling Language (UML) Model Untuk Pengembangan Sistem Informasi Akademik Berbasis Web. Jurnal Informatika: Jurnal Pengembangan IT, 3(1), 126-129.

Ramadhan, A. G., \& Santika, R. R. (2020). AHP dan WP: Metode dalam Membangun Sistem Pendukung Keputusan (SPK) Karyawan Terbaik. Edumatic: Jurnal Pendidikan Informatika, 4(1), 141-150. https://doi.org/10.29408/edumatic.v4i1.2163

Rifai, M. A., Retnoningsih, D., Hari, F., \& Al, S. (2017). Sistem Pelayanan Wisuda Berbasis Web Di Universitas Sahid Surakarta. Jurnal Gaung Informatika, 10(2), 67-78.

Setiawan, A. (2019). Sistem Peminjaman Barang Inventaris Media Perkuliahan Berbasis QR Code Sebagai Pendamping Sistem Konvensional Untuk Pengelolaan Barang. Technologia: Jurnal Ilmiah, 10(3), 134-139.

Sukamto, R. A., \& Shalahuddin, M. (2015). Rekayasa Perangkat Lunak Terstruktur dan Berorientasi Objek.Bandung. Bandung: Informatika.

Susanto, R., \& Andiana, A. D. (2016). Perbandingan Model Waterfall dan Prototyping Untuk Pengembangkan Sistem Informasi. Jurnal Majalah Ilmiah Unikom, 14(1), 41-46. 